\title{
Michèle Audin, Mathematician and Writer
}

\author{
Interviewed by Allyn Jackson
}

In 2014, Michèle Audin retired from her position as professor of mathematics at the University of Strasbourg, in order to devote herself to writing. Her academic output includes about seventy-five research papers in global analysis, differential geometry, topology, and history. She has written several novels, including 121 Days, which was translated into English by Christiana Hills in 2016 and is reviewed in this issue of the Notices. Her article "Differential Geometry, Strasbourg, 1953" appeared in the March 2008 issue of the Notices. Another piece by Audin, "Homage to Henri Cartan (1904-2008)," appeared in the May 2009 issue and includes a short sidebar about Cartan's little-known sister Hélène, who was also a mathematician and became a secondary school teacher.

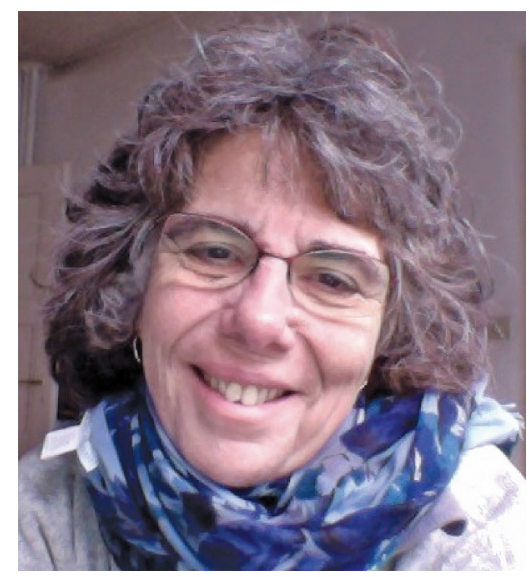

Michèle Audin is the author of the novel 121 Days, reviewed in this issue of the Notices.
Notices: What was your inspiration in writing 121 Days?

Audin: I have done a lot of work on the history of mathematicians living in the first half of twentieth century. I edited correspondence between André Weil and Henri Cartan. I have also written about the way the Jews were forbidden to publish in France during the German occupation. I found some correspondence between two mathematicians at the time of the occupation. One was French, a collaborationist, and the other one German, a member of the army. In their letters, they were very friendly and exchanged very pro-Nazi opinions. I hoped to publish this correspondence, but then I realized the family would never give permission. Even

Allyn Jackson is senior writer and deputy editor of the Notices. Her e-mail address is axj@ams.org.

For permission to reprint this article, please contact: reprint-permission@ams . org.

DOI: http://dx.doi.org/10.1090/noti1545 now, not everybody in France is willing to publicize the fact that he or she had relatives who, seventy-five years ago, collaborated with the Germans. This is one thing that led me to write the novel.

When you say, "So-and-so was French and became a German collaborator," or "this was a bad guy, and that was a good guy"-you are just making an accusation. That was quite the opposite of what I wanted to do. I wanted to have a different kind of freedom, to write something that was not academic research. I wanted to have something more-how to do I say this (very modestly!)? - something more universal. I wanted to write in a different way from a standard paper in history or mathematics and to reach different kinds of readers.

Of course, the main reason was that I wanted to write a novel! [Laughs]

Notices: You are a member of the Oulipo. How did the Oulipo philosophy influence your writing of 121 Days?

Audin: The idea was to use some constraints to build the text. It is a book mainly about mathematicians, so I wanted something using numbers. I made a plan of how to write the book using various constraints, mainly coming from poetry of the Middle Ages, like sestinas. The constraints dictated the order in which things would appear in the
Fiction writing is not very different from writing mathematics.


book. I also tried to show how various materials are used by historians. There is a historian in the book, and he publishes a list of all the materials he used, like newspapers, diaries, testimonies, photographs, and so on.

There are numbers that appear in the book as numbers, but they also appear in the conception of the book. There are eleven chapters and eleven things that appear in all the chapters-a nurse, a dog, and so on-and they appear in a certain order but not always in the same form. There are eleven chapters with eleven things, which makes 121 days!

Notices: Can you tell me about your transition from mathematics to writing?

Audin: It was a very natural process. When I would write mathematics, I always tried to take care to write well. I am not the kind of mathematician who uses only fifty words of vocabulary! I just like to write, and I am happy to write about mathematics or mathematicians or anything else. Fiction writing is not very different from writing mathematics. It uses the same qualities, such as imagination and rigor.

Notices: But when you sit down and write fiction, you get to make everything up, whereas when you write mathematics you are very constrained.

Audin: That's not true. You are very constrained no matter what you write. It's hard work. It's not just sitting down and waiting for inspiration; I don't believe in that. You have to know what you want to say, and why, and how, and you have to organize how you say it. Of course, a mathematician is constrained to write things always in the same order: statement, proof, maybe one example and one conjecture, and that's it. A fiction writer has more freedom.

Notices: Your novel La Formule de Stokes appeared last year [in French only]. Can you tell me about it?

Audin: There are many different forms of the Stokes formula-there was the Gauss formula at the beginning, then the Ostrogradski formula, Green's formula, the Green-Riemann formula, and so on. At the beginning of the twentieth century, under the influence of people like Élie Cartan, the formula became something very abstract and beautiful. The book tells the story of these different forms of the Stokes formula, but it is not written like a history of the formula. It's a series of short stories about the people working on this subject in the nineteenth and twentieth centuries and what happens around them, for example, the political context. And it is not written in a strict chronological order, but like a calendar, so that the first chapter is about events in January, the second about events in February, and so on.

The book is a novel, and the main character is the Stokes formula. The character appears in various contexts, in Russia, in England, in Germany, in France, in Italy. I used some constraints; for example, there is one and only one formula in each story. And they are all different!

Notices: Your father, Maurice Audin, was a mathematician. He was killed by the French army in Algeria in 1957.
You wrote a book about him, Une Vie Brève (A Short Life). What is that book like?

Audin: My father was twenty-five years old when he was killed, so this was a very short life. My problem is that, when people speak of him, they always mention the way he was killed, and that's it. I wanted to collect things about what his life had been, not his death. It's like a biography, but organized differently. It's the collection of everything I found about him in the familial memories and archives.

Notices: Over all these many years, what do you feel now of the influence of your father?

Audin: That's hard. I was $31 / 2$ years old when he was killed. He taught me to read and write, and I was very happy to learn that when I was so young. The main influence is my mother, who was a teacher of mathematics.

Notices: You turned down the Legion d'Honneur some years back. The reason was that then-president Nicolas Sarkozy never responded to a letter from your mother, in which she objected to France not doing enough to look into what happened to your father.

Audin: They did nothing!

Notices: Did you ever get any reply from Sarkozy?

Audin: No. Under President Hollande, the archives have been opened. But I don't think there is anything in the archives, because this was something done secretly by the army. And it was sixty years ago.

Notices: Are you working on something new now?

Audin: I have a book that appeared in 2016, called Mademoiselle Haas. There were so many men in 121 Days that I decided to write a book about women! Mademoiselle Haas is about women working in Paris in the 1930s. None of them are mathematicians-at that time there were very few women mathematicians. And I have another book that will appear in September this year, about the Paris Commune in 1871. It has nothing to do with mathematics, although there are some mathematicians in it.

Notices: One chapter of 121 Days consists of a list of numbers or quantities and what they signify, such as "1 single bullet managed to remove one of M.'s eyes, his nose, and half of his jaw," and "-25, the temperature (in degrees Celsius) in Upper Silesia in January 1945 during the evacuation of Auschwitz." How did you put this chapter together?

Audin: The thing I wanted to show is that numbers are exactly like words. Everybody knows that you can make words say whatever you want them to say. Numbers are the same. I wanted to say that there is nothing objective, no truth in numbers. There is a quotation of Simone de Beauvoir: "There are words as murderous as gas chambers." After the liberation of France, there was a trial of a journalist who was a collaborator. He wrote many things against Jews, including giving addresses where people were hiding. These were just words. But there are words that are murderous. It's just the same with numbers.

\section{Photo Credit}

Photo of Michèle Audin is courtesy of Michèle Audin. 